\title{
A CODIFICAÇÃO DO DIREITO INTERNACIONAL PRIVADO PORTUGUÊS EM PERSPECTIVA, MEIO SÉCULO MAIS TARDE
}

\author{
Rui Manuel Moura Ramos*
}

SUMARIO: 1. INTRODUÇÃO.-2. O PASSADO - O LEGISLADOR DE 1966 NA EVOLUÇÃO DO DIREITO INTERNACIONAL PRIVADO PÁTRIO E NA SITUAÇÃO DA DISCIPLINA AO TEMPO DA OBRA CODIFICADORA.-3. O PRESENTE - A EVOLUÇÃO DO DIREITO INTERNACIONAL PRIVADO PORTUGUÊS POSTERIORMENTE AO CỎDIGO DE 1966.-4. A CODIFICAÇÃO DO DIREITO INTERNACIONAL PRIVADO PORTUGUÊS, NO FUTURO.

\section{INTRODUÇÃO}

1. Com o Código Civil de 1966, entrou em vigor a primeira codificação do direito internacional privado português, constante dos artigos $14 .^{\circ}$ a $65 .^{\circ}$ deste diploma, em termos que permaneceram praticamente intocados até ao presente $^{1}$. Procuraremos proceder a uma breve revisitação daquele texto, no

* Catedrático de Derecho internacional de la Universidad de Coimbra, Portugal (rmmramos@ fd.uc.pt).

1 As alterações verificadas decorreram, essencialmente, do Decreto-Lei n. ${ }^{\circ}$ 496/77, de 25 de Novembro, que, adaptando o direito internacional privado da família aos princípios e regras constitucionais, suprimiu as regras de conflitos (inicialmente contidas nos artigos $58 .^{\circ}$ e $59 .^{\circ}$ ) relativas à legitimação e à filiação ilegítima, respectivamente, substituiu a referência à lei pessoal do marido (constante, respectivamente, do artigo $52 .^{\circ},{ }^{\circ}{ }^{\circ} 2$, e do artigo $53 .^{\circ},{ }^{\circ}{ }^{\circ} 2$, no domínio das relações entre os cônjuges e das convenções antenupciais e regime de bens) pela lei com a qual a vida familiar se ache mais estreitamente conexa e pela lei da primeira residência familiar, reconstruiu, no artigo $56 .^{\circ}$, a regra de conflitos relativa à constituição da filiação, referindo este instituto à lei pessoal do progenitor à data do estabelecimento da relação (n. $\left.{ }^{\circ} 1\right)$, e, no caso de filho de mulher casada, e relativamente ao pai, à lei nacional comum da mãe e do marido, na falta desta, à lei da residência habitual comum dos cônjuges e, se esta também faltar, à lei pessoal do filho (n. $\left.{ }^{\circ} 2\right)$, eliminando a referência à lei pessoal do marido, substituiu as referências à lei pessoal do pai (quando os progenitores não tivessem nem nacionalidade nem residência habitual comum) pela lei nacional do filho, em matéria de relações entre pais e filhos (no artigo $57 .{ }^{\circ}$ ), e à lei pessoal do marido, em matéria de filiação adoptiva (quando a adopção é realizada por marido e mulher ou o adoptando for filho do cônjuge do adoptante e estes não tiverem nem a mesma nacionalidade nem a mesma residência habitual comum), pela lei com a qual a vida familiar dos adoptantes se ache mais estreitamente conexa (artigo $60 .^{\circ}$, n. ${ }^{\circ}$ 2) e eliminou a referência à legitimação no artigo $61 .^{\circ}$ Para além delas, há apenas a mencionar o desdobramento em dois preceitos do 
que se refere ao Capítulo III (Direito dos Estrangeiros e Conflitos de Leis) do Título I (Das leis, sua interpretação e aplicação) do seu Livro I (Parte Geral). Situar-se-á brevemente o conjunto de disposições nele inseridas quer na evolução histórica, no nosso sistema jurídico, do ramo de direito a que se reportam, quer no lugar que ocupam na reflexão que lhes é contemporânea sobre a nossa disciplina. Para indagar em seguida dos termos em que as soluções nelas contidas continuam hoje a impregnar as relações que visam regular, e das perspectivas que a este respeito se abrem. Com o que intentaremos considerar, ainda que em traços muitos breves, o passado, o presente e o futuro da obra empreendida, a este propósito, pelo legislador português vai para cinco décadas.

2. É certo que se não pode considerar que se trate de uma codificação completa e global, nos termos em que hoje a entendemos, uma vez que apenas abrangia a matéria dos conflitos de leis, além de enunciar os princípios gerais aplicáveis no domínio da condição jurídica dos estrangeiros. A opção decorreu, naturalmente, de se entender que as matérias da competência internacional dos tribunais e do reconhecimento das sentenças estrangeiras, porque pertinentes ao direito processual civil, não teriam lugar no diploma fundamental do nosso direito privado ${ }^{2}$. Mas não é menos verdade que se o tratamento destas questões constitui um lugar comum nas leis de direito internacional privado que têm surgido nos últimos tempos ${ }^{3}$, tal não sucedia à época da elaboração do Código de 1966, em que a divisão entre as matérias substantivas e processuais permanecia particularmente bem vincada.

3. E, de todo o modo, sublinhe-se que, no que se refere aos conflitos de leis, a obra realizada se apresenta particularmente conseguida, oferecendonos, além das normas de conflitos sobre a parte especial do direito privado (artigos $25 .^{\circ}$ a $\left.65 .^{\circ}\right)^{4}$, um cuidado tratamento do que se convencionou chamar a parte geral do direito de conflitos (artigos $15 .^{\circ}$ a $\left.24 .^{\circ}\right)^{5}$.

artigo 51. ${ }^{\circ}$, n. ${ }^{\circ} 2$ (operado pelo Decreto-Lei n. ${ }^{\circ} 324 / 2007$, de 28 de Setembro) e do artigo 32. ${ }^{\circ}$,.$^{\circ} 1$, bem como a precisão redaccional feita nestas últimas disposições (pela Lei n. ${ }^{\circ}$ 49/2018, de 14 de Agosto).

Sobre o sentido das alterações em primeiro lugar referidas, cfr. FERrER CorreIA, A., "A Revisão do Código Civil e o Direito Internacional Privado», em Estudos Vários de Direito, Coimbra, 1982, Por Ordem da Universidade, p. 279-307 (286-289), Moura RAMOs, R. M., "A reforma de 1977 e o direito internacional privado da família», em Comemorações dos 35 Anos do Código Civil e dos 25 Anos da Reforma de 1977, vol. I, Direito da Família e das Sucessões, Coimbra, Coimbra Editora, 2004, p. 725-742, e, para um enquadramento global, Moura Ramos, R. M., Direito Internacional Privado e Constituição. Introdução a uma análise das suas relações, 3. ${ }^{a}$ reimpressão, Coimbra, Coimbra Editora, 1994.

2 Contrariamente ao que hoje comummente se entende. Cfr. Lima PinHeIro, L., «A triangularidade do direito internacional privado - Ensaio sobre a articulação entre o Direito de Conflitos, o Direito da Competência Internacional e o Direito de Reconhecimento", em Estudos em Homenagem à Professora Doutora Isabel de Magalhães Collaço, vol. I, Coimbra, Almedina, 2002, p. 311-378. A ideia de uma codificação global, entendida nestes termos, começaria a afirmar-se a partir da lei federal suíça de 1987 sobre o direito internacional privado.

3 Vejam-se os dados que indicamos, a este propósito, no nosso estudo «O direito processual civil internacional no novo Código de Processo Civil», 143 Revista de Legislação e de Jurisprudência (Novembro-Dezembro 2013), n. ${ }^{\circ} 3.983$, p. 82-106, notas 11 a 20.

4 Trata-se da Secção II do Capítulo III, epigrafada «Normas de conflitos» e subdividida em seis subsecções, dedicadas, respectivamente, ao âmbito e determinação da lei pessoal (artigos $25 .^{\circ}$ a $34 .^{\circ}$ ), e 


\section{O PASSADO - O LEGISLADOR DE 1966 NA EVOLUÇÃO DO DIREITO INTERNACIONAL PRIVADO PÁTRIO E NA SITUAÇÃO DA DISCIPLINA AO TEMPO DA OBRA CODIFICADORA}

4. Anteriormente ao Código de 1966, a disciplina dos conflitos de leis encontrava-se dispersa por diversos preceitos do Código de Seabra ${ }^{6}$ a que o intérprete recorria em sede de designação da lei aplicável às relações plurilocalizadas de carácter privado. O carácter fragmentário e lacunar desta regulamentação era no entanto particularmente reconhecido pela nossa doutrina, que não hesitava em considerar tais disposições ${ }^{7}$ como das «mais pobres e menos definidas no direito europeu» ${ }^{8}$.

5. Idêntico juízo não tem já qualquer cabimento perante o sistema consagrado no Código de 1966, que na doutrina estrangeira ${ }^{9}$ já se reconheceu constituir a mais aperfeiçoada das codificações incluídas no grupo da segunda geração ${ }^{10}$. Na verdade, o texto em causa, seguindo em termos bastante

à lei reguladora dos negócios jurídicos (artigos $35 .^{\circ}$ a $\left.40 .^{\circ}\right)$, das obrigações $\left(\operatorname{artigos~} 41 .^{\circ}\right.$ a $\left.45 .^{\circ}\right)$, das coisas (artigos $46 .^{\circ}$ a $\left.48 .^{\circ}\right)$, das relações de família (artigos $49 .^{\circ}$ a $61 .^{\circ}$ ) e das sucessões (artigos $62 .^{\circ}$ a $65 .^{\circ}$ ).

${ }^{5} \mathrm{Na}$ Secção I do mesmo Capítulo, intitulada «Disposições Gerais». Para um comentário a este capítulo, cfr. a obra de De Almeida Pires, F., Conflitos de leis. Comentário aos artigos $14 .^{\circ}$ a $65 .^{\circ}$ do Código Civil, Coimbra, Coimbra Editora, 2009.

${ }^{6}$ Que incluía igualmente os princípios relativos aos conflitos de jurisdições. Tratava-se do primeiro Código Civil Português, aprovado por Carta de Lei de 1 de Julho de 1867 e cuja fonte inspiradora essencial foi o Code Napoléon, de 1804.

7 Designadamente os artigos $24 .^{\circ}$ e $27 .^{\circ}$ do Código, sobre, respectivamente, o estatuto legal dos cidadãos portugueses em país estrangeiro e o estado e a capacidade civil dos estrangeiros em Portugal, que seriam objecto de detalhada análise de TeIXEIRA DE ABReu, A. J., em Estudos sobre o Código Civil Português. II - Das Relações Civis Internacionais, Coimbra, Imprensa Académica, 1894, p. 42-50, 6173, 88-92, 97-115, 118-131, e 134-135, e de Machado Vilela, A., Tratado Elementar (Teórico e Prático) de Direito Internacional Privado, Livro II - Aplicações, Coimbra, Coimbra Editora, 1922. Cfr. ainda Fernandes Falcão, L., Do Direito Internacional Privado, Coimbra, Imprensa da Universidade, 1868, p. 191-194, 221-222, 229-250, 307, 332-334, 335-338, e 343-347, Guimarães Pedrosa, A. L., Introdução ao Estudo do Direito Privado Internacional, Coimbra, Imprensa da Universidade, 1878, p. 172-173, e, em matéria sucessória, Dos ReIs, J. A., Das Sucessões no Direito Internacional Privado, Coimbra, 1899, FranÇA Amado, F. (ed.), p. 92-142, 148-193, e 196-270.

8 Assim Machado Vilela, A., a abrir o seu O Direito Internacional Privado no Código Civil Brasileiro, Coimbra, Imprensa da Universidade, 1921, p. V. Mas note-se que este juízo era partilhado pelos demais autores citados na nota anterior. Vilela salientava expressamente a vantagem que o legislador português teria em seguir o exemplo do Código Civil Brasileiro (de 1916, de Clóvis Bevilaqua), que considerava assentar num sistema bastante completo de princípios gerais; sobre a sua obra, cfr., recentemente, Moura Ramos, R. M., «Machado Villela, o Primeiro Internacionalista Português da Contemporaneidade», em Machado Villela, A., Conflitos entre as Leis Portuguesas e as Leis Brasileiras em Matéria de Nacionalidade; com texto de Rui Manuel Moura Ramos, Coimbra: Instituto Jurídico (Cadernos do Centenário; Patronos; Direito Internacional Privado), 2018, p. 71-140.

9 A apreciação é de BALlaRino, T., no seu "Lineamenti comparati delle riforme del diritto internazionale privato nell'Europa centro-orientale», in Current trends of conflict of laws in central-eastern Europe, Universita degli studi di Trieste, 1984, p. 31-44, a p. 38.

10 Assim, para o Autor que estamos a citar (supra, na nota anterior), o grupo que incluía, para além da codificação portuguesa, as codificações polacas de 1926 e 1966, a brasileira de 1942, a checoslovaca de 1964, a albanesa de 1965 e a espanhola de 1974.

Sobre esta última, ou seja, a reforma levada a cabo pelo Decreto 1836/74, de 31 de Maio, cfr, por exemplo, Carrillo Salcedo, J. A., "Le nouveau droit international privé espagnol», Ann. suisse dr. int., 
próximos os trabalhos preparatórios (os dois Anteprojectos de Ferrer Correia ${ }^{11}$, publicados, respectivamente em $1951^{12}$ e $\left.1964^{13}\right)$, poderia perfeitamente constituir uma lei geral de direito internacional privado (conquanto restrita à matéria dos conflitos de leis), do tipo das que, sobretudo a partir da década de 80, surgiram em diversos países, dentro e fora do espaço europeu. O que significa que, com o Código de 1966, se operou o trânsito de um acervo limitado e incompleto de regras manifestamente insuficientes para um conjunto ordenado e coerente, que obedecia a princípios comuns e se orientava por uma ideia de justiça que se queria típica do direito internacional privado. Nesse sentido, pode dizer-se que nos passámos a encontrar face a um sistema. E um sistema que, quando comparado com os precedentes existentes, a eles nada ficava a dever.

6. Uma primeira característica deste sistema, como vimos, reside na circunstância de ele distinguir nitidamente, a exemplo do que constituía uma nota comum dos trabalhos científicos sobre a matéria, a parte geral (onde tinham assento as questões típicas da operação de toda e qualquer regra de conflitos, e portanto, comuns a todas elas) da parte especial, integrada pelas regras específicas que continham a particular disciplina conflitual (relativa à designação da lei aplicável) de cada questão jurídica de direito privado. E de, quer a parte geral quer a parte especial, apresentarem, na nossa lei civil, um desenvolvimento superior (quase que diríamos uma especialização, no que poderia estar em causa a antecipação de tendências que se viriam a desenvolver posteriormente) ao que caracterizava, ao tempo, as codificações congéneres.

vol. XXXII, 1976, p. 9-35, CASTÁn VÁzoueZ, J. M., «La réforme du titre préliminaire du Code Civil espagnol», Rev. int. dr. comp., 1974, p. 835-844, CREMADES SANZ-PASTOR, J. A., "Droit international prive», J. Cl. dr. comp., Législation comparée, Espagne, fasc. 11, 1974, p. 257-296, Cremades, B. M. y MACEDA, A., «Das neue spanische IPR», RIW, 1975, p. 375-379, FERnÁNDEZ RozAs, J. C., Tráfico jurídico externo y sistema de DIPr, 2. ${ }^{\text {a }}$ ed. rev., Oviedo, Apel, 1985, p. 173-180, id., "Private International Law», Spanish Business Law (B. M. Cremades ed.), Deventer, Kluwer, 1985, p. 51-70, Iglesias Buhigues, J. L., "Le nouveau système de règles de conflit du droit international privé espagnol», Rev. crit. dr. int. pr., 1976, p. 397-423, Marín LóPEZ, A., «El DIPr en el Título Preliminar del Código Civil», Revista Profesional del Ilustre Colegio de Abogados de Granada, n. ${ }^{\circ}$ 98, 1974, p. 419-433, PAGLIA, M. C., "Comentarios a las normas de DIPr español en el nuevo Título Preliminar del Código Civil», Gaceta del Notariado (Rosario), n. ${ }^{\circ}$ 71, 1977, p. 131 ss., SÁNCHEZ-APELlÁNIZ VALDERRAMA, F., «La reforma del sistema español de DIPr», Doc. Jur., 1974, p. 1137-1157, Serrano Alonso, E., "Aproximación al Título Preliminar del Código Civil», Boletín del Ilustre Colegio de Abogados de Oviedo, n. ${ }^{\circ}$, 1974 (anexo), e Von Hoffman, B. y OrTíz-ARce, A., "Das neue spanische internationale Privatrecht», Rabels Z., 1975, p. 647-691 (texto modificado em castelhano en REDI, vol. XXX, 1977, p. 57-89). E para um balanço e uma perspectiva Fernández Rozas, J. C., «El Capítulo IV del Título Preliminar del Código civil ("Normas de Derecho internacional privado"): Veinticinco años después», em Homenaje a Antonio Hernández, Gil, Madrid, Colegio de Abogados de Madrid, 2001, p. 2411-2447.

11 Sobre a contribuição deste Autor, cfr. Moura Ramos, R. M., «Ferrer Correia e a codificação do Direito Português, em particular do Direito Internacional Privado", 142. ${ }^{\circ}$ Revista de Legislação e de Jurisprudência (Setembro-Outubro 2012), n. ${ }^{\circ}$ 3976, p. 4-30.

12 Ferrer Correia, A., «Direito Internacional Privado. Direito dos Estrangeiros», in Boletim do Ministério da Justiça, n. ${ }^{\circ} 24$ (Maio de 1951), p. 9-71.

13 Ferrer Correia, A. (com a colaboração de Baptista Machado), «Aplicação das Leis no Espaço. Direitos dos Estrangeiros e Conflitos de Leis», Boletim do Ministério da Justiça, n. ${ }^{\circ} 136$ (Maio de 1964), p. 17-72. 
7. Por outro lado, e no mesmo sentido vertebrador, o Código assumiu claramente uma ideia de justiça internacionalprivatística (kollisionsrechtliche Gerechtigkeit) nos termos da qual a definição da lei competente em cada caso decorria da "relação em que ela se encontra com a situação de facto a regular», e não "da justiça maior ou menor dos seus preceitos» (materiellrechtliche Gerechtigkeit), o que conduzia à escolha, não da «melhor lei, mas [d]a melhor colocada para intervir - em razão, claro está, da sua posição espacial relativamente aos factos, ou de uma relação com as pessoas a quem estes respeitam ${ }^{14}$, no que se entendia, dada a relatividade (espacial) inerente à noção de justiça, ser a única forma de assegurar a harmonia jurídica internacional. $\mathrm{E}$ a ideia de que este critério de decisão (do qual, como teremos ocasião de verificar, o legislador se afastou não poucas vezes, preterindo-o em favor de outros) ${ }^{15}$ assumia uma centralidade nesse processo de escolha levou ao reconhecimento de um princípio de paridade entre as distintas ordens jurídicas, que implicava não reconhecer à lex fori uma qualquer posição preferencial, antes fazendo depender in casu a sua competência da verificação do mesmo elemento (em princípio a referida posição espacial relativa aos factos ou às pessoas a quem estes respeitam $)^{16}$ que, quando preenchido em relação a uma outra, igualmente determinaria a respectiva competência. Concepção que estava na base do reconhecimento do carácter bilateral ou plurilateral da regra de direito internacional privado (a regra de conflitos, tal como ela surgia na parte especial) ${ }^{17}$, de que só em circunstâncias muito limitadas o nosso legislador se afastou ${ }^{18}$, e que iluminaria particularmente o sentido da resolução de algumas das questões tratadas na parte geral.

14 Assim Ferrer Correia, A., "O novo direito internacional privado português (Alguns princípios gerais)», in Estudos Vários de Direito (cit. supra, nota 1), p. 3-57 (10-11). A contraposição que se faz em texto corresponde assim aos dois tipos de regras de conflitos identificados por Michele PATOCCHI, P. no seu estudo Règles de Conflit Localisatrices et Règles de Conflit à Rattachement Matériel. De quelques aspects récents de la diversification de la méthode conflictuelle en Europe, Genève, Georg, 1985.

15 Designadamente da própria justiça material, ou de uma sua concretização, o que conduzia em linha recta a uma certa materialização do direito internacional privado.

16 E por isso designado por elemento ou factor de conexão.

17 Regra esta que o legislador via fundamentalmente como uma regra de conflitos rígida (no sentido de não particularmente aberta à modelação judicial) em que o legislador cristalizava em cada disposição o princípio da conexão mais estreita, não se limitando, na formulação certeira e impressiva de KAHN-Freund, O., "La notion anglaise de la "proper law of the contract" devant le juge et devant les arbitres. Ses développements récents et ses affinités avec l'Avant-projet européen d'unification des règles de conflit en la matière», Revue Critique de Droit International Privé, 62 (1973), p. 607-627 (614615), a substituir "la raison de faire une règle à la règle elle-même».

No sistema português, a flexibilização das regras de conflitos, só surgiria, com efeito, com a Reforma de 1977 (cfr. supra, na nota 1), em que o legislador passou a recorrer, em certos casos, como vimos, na falta de nacionalidade e residência habitual comum dos cônjuges, à lei com a qual a vida familiar se ache mais estreitamente conexa (no artigo 52..$^{\circ}$ n..$^{\circ}$ 2), e à lei com a qual a vida familiar dos adoptantes se ache mais estreitamente conexa (no artigo $60 .^{\circ},{ }^{\circ}{ }^{2}$ ). E para desenvolvimentos subsequentes, induzidos pelo direito convencional, cfr. Moura RAMOS, R. M., «Previsão normativa e modelação judicial nas convenções comunitárias relativas ao direito internacional privado", in O Direito Comunitário e a Construção Europeia, (Stvdia Ivridica, 38. Colloquia - 1), Coimbra, Coimbra Editora, 1999, p. 93-124.

18 No artigo $28 .^{\circ}$, n. $^{\circ} 1$ (mas aí com um carácter bem circunscrito, dada a delimitação da hipótese feita no $\mathrm{n} .^{\circ} 2$, e admitindo apesar disso, e logo em seguida, no n. ${ }^{\circ}$ 3, o regresso à matriz inspiradora do sistema) e no artigo $51 .^{\circ}$, onde se consagram regras bilaterais imperfeitas, que apenas se referem «a 
8. No que respeita, agora, à parte geral do sistema de direito internacional privado constante do Código Civil, uma das suas características é o desenvolvimento que, em relação às congéneres de outros sistemas, apresenta. Assim, nas referidas Disposições Gerais ${ }^{19}$, vamos encontrar, para além de um princípio geral relativo à condição jurídica dos estrangeiros ${ }^{20}$, e de uma regra relativa aos actos realizados a bordo de navios ou aeronaves, fora dos portos ou aeródromos ${ }^{21}$, normas relativas a seis dos problemas (a qualificação ${ }^{22}$, o reenvio $^{23}$, a referência a ordenamentos plurilegislativos ${ }^{24}$, a aplicação do direito estrangeiro ${ }^{25}$, a ordem pública ${ }^{26}$ e a fraude à lei ${ }^{27}$ ) usualmente tratados na parte geral. Para além deste desenvolvimento, a doutrina salientou a cor-

situações que mantenham com o Estado do foro uma dada conexão (e não a todas as situações, incluindo aquelas que não tenham com o dito Estado aquela ou até qualquer outra conexão), só para essas determinando a lei aplicável, podendo esta ser a lei do foro ou uma lei estrangeira, conforme a que for apontada por uma outra conexão, considerada decisiva» (assim BAPTISTA MACHADO, J., Lições de Direito Internacional Privado, 2. ' edição, Coimbra, Almedina, 1982, p. 70).

19 Supra, em texto junto à nota 5.

$20 \mathrm{O}$ artigo $14 .^{\circ}$, onde se consagra no n. ${ }^{\circ} 1$, mas admitindo ressalva em contrário, o princípio da equiparação em matéria de direitos civis, que constava já do artigo 24 . $^{\circ}$ do Código de Seabra, temperado no n. ${ }^{\circ} 2$ por uma regra de retorsão, nos casos em que o respectivo Estado nacional, atribuindo certos direitos aos seus cidadãos, os negue aos portugueses em igualdade de circunstâncias.

${ }^{21} \mathrm{O}$ artigo $24 .^{\circ}$, que consagra no $\mathrm{n} .^{\circ} 1$, a competência da lei do lugar da respectiva matrícula, sempre que for competente a lei territorial, e que considera, no n. ${ }^{\circ} 2$, os navios e aeronaves militares parte do território do Estado a que pertencem. Sobre o ponto, cfr. LIMA PINHEIRO, L. «Temas de Direito Marítimo. II. O Navio em Direito Internacional», $R O A$, n. ${ }^{\circ} 71,2011$, p. 447-476.

22 Artigo 15. Sobre este problema, cfr. os trabalhos de ANCEL, B., "L'objet de la qualification», Journal de Droit International, vol. 107, n. ${ }^{\circ}$ 2, 1980, p. 227-268, GrundmanN, S., Qualifikation gegen die Sachnorm. Deutsch-portugiesische Beitrage zur Autonomie des internationalen Privatrechts, Munchen, 1985, C. H. Beck; Bernasconi, C., Der Qualifikationsprozess im internationalen Privatrecht, Zurich, Schulthess Polygraphischer Verlag, 1997; Hernández-Bretón, E., «An attempt to regulate the problem of «characterization» in private international law», in Festschrift fur Erik Jayme, t. I, Munchen, Sellier, 2004, p. 331-338, e BouKHARI, R., "La qualification en droit international privé», Les Cahiers de droit, vol. 511, 2010, p. 159-193.

${ }^{23}$ Artigos $16 .^{\circ}$ a $19 .^{\circ}$ A regulamentação desta questão compreende ainda os artigos $36 .^{\circ}$, n..$^{\circ} 2$, e $65 .^{\circ}$, n. ${ }^{\circ} 1$, in fine. Sobre este instituto, por último, cfr. DAvI, A., "Le renvoi en droit international privé contemporain", Recueil des Cours, t. 352, 2010, p. 9-522, a esgotante investigação de Romano, G. P., Le dilemme du renvoi en droit international privé. La thèse, l'antithèse, et la recherche d'une synthèse, Zurich, 2014, Schulthess, e KASSIR, W. J., "Le renvoi en droit international privé - technique de dialogue entre les cultures juridiques», Recueil des Cours, t. 377, 2018, p. 9-120.

24 Artigo 20. ${ }^{\circ}$ Sobre esta temática, cfr. Graveson, R. H., "Problems of private international law in non-unified legal systems», Recueil des Cours, t. 141, 1974-II, p. 187-254; BorRÁs, A., "Les ordres plurilégislatifs dans le droit international privé actuel», Recueil des Cours, t. 249, 1994, p. 145-368, ÁLVAREz GonzÁlez, S., Estudios de Derecho Interregional, 2007, Universidad de Santiago de Compostela, e PARISOT, V., «Les classifications des conflits internes de lois à l'épreuve de leur solution», Rev. crit. DIP, vol. 103, 2014, p. 469-512.

${ }^{25}$ Artigo 23. ${ }^{\circ}$ A este respeito, cfr. Marques dos Santos, A., "A aplicação do direito estrangeiro», Revista da Ordem dos Advogados, vol. 60, 2000, p. 647-668, JANTERA-JAREBORG, M., "Foreign Law in National Courts: A Comparative Perspective», Recueil des Cours, t. 304 2003, p. 181-386, GeERoms, S., Foreign Law in Civil Litigation. A Comparative and Functional Analysis, Oxford, Oxford University Press, 2004; Hausmann, R., "Pleading of proof of Foreign Law - a Comparative Analysis», The European Legal Forum, vol. 8, January-February 2008, Section I, p. 1-13, Esplugues MotA, C., IgLEsias BuHigues J. L. e Palao Moreno, G. (eds.), Application of Foreign Law, Munich, Sellier - European Law Publishers, 2011; Moura Ramos, R. M., "Proof of and Information about foreign law», Boletim da Faculdade de Direito, vol. 90, t. 1, 2014, p. 431-448, e Nishitani, Y. (ed.), Treatment of Foreign Law. Dynamics towards Convergence?, Springer, 2017.

(Véanse notas 26 y 27 en página siguiente) 
recção e a originalidade ${ }^{28}$ das soluções, que justificaram o interesse despertado além-fronteiras pela nova codificação ${ }^{29}$, tendo-se inclusivamente referido mais perto de nós que elas poderiam servir de modelo inspirador para um sistema de direito internacional privado da União Europeia ${ }^{30}$.

9. Na verdade, as soluções adoptadas a este respeito são em grande medida tributárias da preocupação com a realização da harmonia jurídica internacional, respeitando também, nessa medida, o princípio da paridade de tratamento entre a lex fori e as leis estrangeiras. É o que se passa com o domínio da qualificação, onde é rejeitada claramente a tese da qualificação lege fori, sendo a qualificação primária substituída por uma norma narrativa que descreve o método da qualificação ${ }^{31}$. Com a questão do reenvio, cuja regulamentação é claramente inspirada pelos mesmos princípios, nomeadamente o da harmonia jurídica internacional, numa posição altruísta ${ }^{32}$, se bem que não deixe de atender a outras determinantes, e ainda com a disciplina relativa à referência a ordenamentos plurilegislativos (de natureza territorial ou pessoal $)^{33}$, claramente inspirada pela preocupação de resolver o caso da

26 Artigo 22. ${ }^{\circ}$ Sobre o tema, vejam-se Moura Ramos, R. M., «L'ordre public international en droit portugais», Boletim da Faculdade de Direito, V.74, 1998, p. 45-62, e, mais em geral, BucHER, A., "L'ordre public et le but social des lois en droit international privé», Recueil des Cours, t. 239, 1993-II, p. 11-116, e De Vareilles-Sommières, P., "L'exception d'ordre public et la régularité substantielle internationale de la loi étrangère», Recueil des Cours, t. 371, 2015, p. 153-272.

27 Artigo 21. ${ }^{\circ}$ Sobre esta figura, cfr. os trabalhos de Audit, B., La Fraude à la Loi, Paris, Dalloz, 1974; Mosconi, F., "Exceptions to the Operation of Choice of Law Rules», Recueil des Cours, t. 217, 1989-V, p. 9-214, e CoRnu, E., Théorie Critique de la Fraude à la Loi. Étude de Droit International Privé de la Famille, Paris, Defrénois, 2006.

28 Depois de Wilhelm Wengler ter sublinhado o conhecimento revelado pelos seus autores das novas (ao tempo) doutrinas científicas, nomeadamente da doutrina alemã, que no seu entender superariam os habitualmente encontrados na própria Alemanha [WENGLER, W., «Der Entwurf für ein neues portugiesisches Zivilgesetzbuch», Archiv für civilistische Praxis, vol. 167, 1967, p. 64-69, esp. 65, a originalidade do novo texto seria salientada por KoKKINI-IATRIDOU, D., "Legislation in the field of private international law», Les Législations de Droit International Privé. Conflits de Lois et Conflits de Juridictions, Oslo, Universitetsforlaget, 1971, p. 3-21, esp. p. 10, que sublinha a existência de "certain provisions particularly worthy of note and which in our opinion impart to it an "air of originality" compared to those of other European countries»], Von OvERBEcK, A.: "Tant pour la forme que pour le fond, il s'agit d'une oeuvre originale contenant beaucoup de solutions qu'on ne retrouve pas ailleurs", en "Les questions générales du droit international privé à la lumière des codifications et projets récents. Cours général de droit international privé», Recueil des Cours, t. 176, 1982-III, p. 9-258, esp. p. 35-36, e, mais recentemente, por JAYME, E., «António Ferrer Correia und die Kodifikation des portugiesischen Internationalen Privatrechts», en Internationaler Rechtsverkehr und Rechtevereinheitlichung aus deutsch-lusitanischer Perspektive, Baden-Baden, Nomos Verlagsgesellschaft, 2014, p. 13-25, esp. p. 15.

${ }_{29}$ Veja-se sobretudo a monografia de García Velasco, I., Concepción del derecho internacional privado en el nuevo código civil portugués, Universidade de Salamanca, 1971.

30 Assim Jayme, E., op. cit., nota 28, p. 15-16, e Lima PinHeIro, L. «The Methodology and the general part of the Portuguese private international law codification: a possible source of inspiration for the European legislator?», Yearbook of Private International Law, vol. 14, 2013/2014, p. 153-172.

31 Neste sentido JaYMe, E., op. cit., nota 28, p. 17. Cfr. ainda Von OverbecK, A., op. cit., nota 28, p. 108-112, a monografia de GrUNDMANN, S., op. cit., nota 22, e, para um confronto com outras (raras) soluções no plano legislativo, Hernández-Bretón, E., op. cit., nota 22.

32 Assim se lhe refere Von Overbeck, A., op. cit., nota 28, p. 141-145, que salienta o seu carácter "très élaboré» e a circunstância de as suas ramificações serem «tout à fait logiques».

33 A previsão desta hipótese é expressamente saudada por David Cavers, que num estudo comparativo CAVERS, D., «Legislative choice of law: Some European examples», Southern California Law Review, vol. 44, 
mesma forma que ele seria decidido no sistema complexo designado. E o mesmo deve dizer-se da regra relativa aos termos da interpretação do direito estrangeiro aplicável ${ }^{34}$, e, agora também quanto à limitação ao mínimo do recurso à lex fori, da disciplina prevista para os casos de impossibilidade quer de averiguação do conteúdo da lei estrangeira aplicável quer de determinação dos elementos de facto e de direito de que depende a sua designação ${ }^{35}$, assim como da solução adoptada ${ }^{36}$ para a hipótese de actuação da excepção de ordem pública internacional: em todas estas situações a utilização da lex fori surge realmente como um último recurso.

10. Poderemos fazer um juízo semelhante se atentarmos agora nas regras da parte especial. A este respeito, e quanto à lei pessoal, considere-se o amplo âmbito de actuação que lhe é reconhecido, no caso das pessoas físicas $^{37}$, e, quanto à respectiva determinação, apesar da preferência pela lex patriae, o domínio reservado à lei da residência habitual ${ }^{38}$, quer no caso dos apátridas $^{39}$, quer em geral, por força de uma regra de reconhecimento a que a doutrina estrangeira não deixaria de dedicar a devida atenção ${ }^{40}$. Trata-se, na verdade, de uma disposição que reconhece a vocação daquelas duas leis para regular as matérias do estatuto pessoal e que procura retirar daí os respectivos efeitos quanto ao reconhecimento dos negócios jurídicos celebrados de acordo com elas, mesmo tratando-se de cidadãos portugueses no estrangeiro $^{41}$. E tenha-se em conta a regulação da lei aplicável às pessoas colectivas, incluindo as de natureza internacional.

11. Em sede de lei reguladora dos negócios jurídicos, por seu lado, saliente-se a introdução de preocupações de carácter substantivo em matéria de forma (artigo $\left.36 .^{\circ}\right)^{42}$, o acerto da regulamentação adoptada quanto à disci-

1970-1971, p. 340-361, nota ser o direito português o único entre os sistemas considerados (as Disposições Preliminares do Código Civil Italiano de 1942, o Projet de loi complétant le Code civil en matière de droit international privé, de 1970, da Comissão presidida em França por Henri Batiffol, e o Traité Benelux portant loi uniforme relative au droit international privé, de 3 de Julho de 1969), que aborda esta questão (p. 349-350).

${ }^{34}$ Contida no artigo $23 .^{\circ}, \mathrm{n} .^{\circ} 1$, e segundo a qual ela deve ter lugar dentro do sistema a que pertence e de acordo com as regras interpretativas nele fixadas. A este respeito, cfr. por último MourA RAmos, R. M., op. cit., supra, nota 25.

35 Artigo $23 .^{\circ},{ }^{\circ} .^{\circ} 2$, e artigo $348 .^{\circ}$, maxime n. ${ }^{\circ} 3$.

36 No artigo $22 .^{\circ}$, n. $^{\circ} 2$.

37 Âmbito que engloba, além do estado, da capacidade e das relações de família, também o domínio das sucessões por morte.

38 Igualmente salientado por KoKKINI-IATRIDOU, D., op. cit., supra, nota 28, p. 9-10.

39 Artigo 32.

40 Von OverbecK, A., op. cit., nota 28, p. 175, sublinharia aprovativamente que «chaque système de droit international privé national peut poser expressément les limites de sa propre application ou dégager des règles jurisprudentielles dans ce sens».

Sobre aquela regra, cfr. Moura Ramos, R. M., «Dos Direitos Adquiridos em Direito Internacional Privado», BFDUC, vol. L, 1974, p. 175-217, e, por último, MourA ViCENTE, D., «La reconnaissance au Portugal des situations juridiques constituées à l'étranger», Droit International Privé, Année 2014-2016, Paris, Éditions A. Pedone, 2017, p. 263-286.

41 Em situações, pois, em que a lei portuguesa seria competente. Ver o que se disse na nota anterior.

42 Através de uma conexão alternativa, no artigo $36 .^{\circ},{ }^{\circ}{ }^{\circ} 2$, que dá relevância à lei da substância do negócio e à lei do lugar da celebração. Vide também, em especial quanto aos testamentos, o artigo 65. ${ }^{\circ}$, n. ${ }^{\circ} 1$. 
plina da declaração negocial (artigo $\left.35^{\circ}\right)^{43}$, o cuidado regime dos vários tipos de representação (artigos $37 .^{\circ}$ a $39 .^{\circ}$ ) e a resolução do clássico problema de qualificação posto pela prescrição, em termos de sujeitar este instituto (bem como o da caducidade) a uma qualificação substantiva, fazendo-os regular pela lei do direito a que respeitam (artigo $40 .^{\circ}$ ).

12. Mas é sobretudo em matéria de lei reguladora das obrigações que as soluções merecem um maior aplauso. Não tanto pela determinação da lei aplicável aos contratos, onde há de qualquer modo que saudar o amplo reconhecimento do princípio da autonomia das partes (artigo 41. $\left.{ }^{\circ}\right)^{44}$, diferentemente do que sucede na conexão subsidiária (artigo $42 .^{\circ}$ ) onde, embora tendo optado pela lei da residência habitual comum, o legislador não se conseguiu desprender, ainda que a título residual, da herança da lex loci celebrationis $^{45}$. Mas pela cuidada regulação das situações de gestão de negócios (artigo $43 . .^{\circ}$ ) e de enriquecimento sem causa (artigo $44 .^{\circ}$ ), que pouco se afasta da actualmente preconizada ${ }^{46}$. E, sobretudo, pela disciplina da responsabilidade civil (artigo $45 .^{\circ}$ ), onde o Código, partindo embora da clássica lex loci delicti commissi, entendida como lei do lugar do facto gerador (artigo 45. ${ }^{\circ}$, n. ${ }^{\circ} 1$ ), lhe prefere (no n. ${ }^{\circ} 2$ ), numa norma de conflitos de conexão material, a lei do lugar do efeito lesivo (lex damni), quando esta «considerar responsável o agente, mas não o considerar como tal a lei do país onde decorreu a sua actividade, desde que o agente devesse prever a produção de um dano, naquele país, como consequência do seu acto ou omissão» ${ }^{47}$, ao mesmo tempo que limita a aplicação de ambas estas leis, ao considerar, no n. ${ }^{\circ} 3$, que "se o agente e o lesado tiverem a mesma nacionalidade ou, na falta dela, a mesma residência habitual, e se encontrarem ocasionalmente em país estrangeiro, a lei aplicável será a da nacionalidade ou a da residência comum, sem prejuízo das disposições do Estado local que devam ser aplicadas indistintamente a todas as pessoas» ${ }^{48}$.

43 Com a sua sujeição à lei reguladora do negócio projectado, sem prejuízo da autonomização da questão do valor jurídico do silêncio (e em particular do seu valor negativo), a disciplinar pela lei do ambiente negocial.

${ }_{44}$ CAVERS, D., op. cit., nota 33, p. 348 e nota 32, sublinha, no estudo acima referido que os limites à autonomia coincidem com os que vieram a ser estabelecidos pelo Restatement Second Conflict of Laws, de 1971.

45 Verberada por CAVERS, D., op. cit., nota 33, p. 349 como «that most persistent of legal anachronisms».

46 Cfr., respectivamente, os artigos $11 .^{\circ}$ e $10{ }^{\circ}$, do Regulamento (CE) n. ${ }^{\circ}$ 864/2007, do Parlamento e do Conselho, de 11 de Julho de 2007, relativo à lei aplicável às obrigações extracontratuais (Roma II).

47 Formulação que lembra, curiosamente, os principles of preference de CAVERS, D., op. cit., nota 33, p. 354. Este autor vê, aliás, no direito português a preocupação de aumentar a protecção das vítimas dos acidentes. Ainda sobre o relevo reconhecido a esta tendência, cfr. GaUdemet-TaLlon, H., "Protection de la victime et évolution du droit international privé de la responsabilité délictuelle», en Études à la Mémoire du Professeur Bruno Oppetit, Paris, LexisNexis, 2009, p. 261-280

48 Symeonides, S., Codifying Choice of Law around the World. An International Comparative Analysis, Oxford, Oxford University Press, 2014, p. 87-88, salienta o carácter pioneiro da introdução desta disposição e a diferenciação por ela introduzida entre dois tipos de regras (as regras de segurança e conduta e as demais, a que, na doutrina norte-americana, corresponde a contraposição entre conductregulating rules e loss-allocation rules). 
13. Já em sede de lei reguladora das coisas o Código se não afasta do classicismo da lex rei sitae, não sem prever o particularismo das coisas em trânsito e dos meios de transporte submetidos a um regime de matrícula (artigo 46..$^{\circ}$, e sem estender, numa aplicação do princípio da Naherberechtigung, a aplicação daquela lei, em matéria de capacidade para constituir direitos reais sobre coisas imóveis ou para dispor deles, desde que ela assim o determine (artigo 47. ${ }^{\mathrm{a}}$ ), ocupando-se ainda da propriedade intelectual (artigo 49..$^{\circ}{ }^{49}$.

14. As relações de família constituem o domínio em que a regulamentação é mais extensa (artigos $49 .^{\circ}$ a $61 .^{\circ}$ ), ocupando-se do casamento -como acto (quanto à forma e à substância) e como estado (quer nas relações pessoais quer nas patrimoniais)—, da filiação, e da adopção (em ambos os casos quanto ao estabelecimento e aos efeitos, concretizando o critério da lei nacional e optando por uma ligação estreita ao quadro de opções do direito material respectivo.

15. Finalmente, ainda no domínio do estatuto pessoal e em matéria de sucessões (artigos 62. ${ }^{\circ}$ a $65 .^{\circ}$ ), o Código estabelece as regras fundamentais, resolvendo ainda problemas de qualificação ${ }^{50}$ que se haviam suscitado na prática.

16. Pode assim concluir-se, pese embora a falta de preocupações de exaustividade que caracterizou a breve referência que acabámos de fazer, que a codificação do direito internacional privado empreendida com o Código Civil de 1966 se revelou um texto completo e modelar, dotado de uma unidade de concepção e de uma coerência interna assinaláveis e que não sofre de modo nenhum numa comparação com iniciativas coevas de carácter semelhante.

\section{O PRESENTE - A EVOLUÇÃO DO DIREITO INTERNACIONAL PRIVADO PORTUGUÊS POSTERIORMENTE AO CÓDIGO DE 1966}

17. Os méritos que não podem deixar de ser reconhecidos à codificação do direito internacional privado português levada a cabo no Código Civil de 1966 não impediram, no entanto, que o corpus da nossa disciplina se apresente hoje em termos sensivelmente diferentes da construção a que nos temos vindo a referir, permitindo concluir que o direito internacional privado aplicável em Portugal se foi progressivamente afastando, no último meio século, das soluções acolhidas naquele diploma ${ }^{51}$.

49 Cfr., sobre o ponto, Moura ViCEnTE, D., «La propriété intellectuelle en droit international privé», Recueil des Cours, t. 335, 2008-III, p. 105-504, e "Droit international privé et immatériel au Portugal», en L'Immatériel. Journées Espagnoles, Travaux de l'Association Henri Capitant, vol. LXIV (2014), Bruxelles, Bruylant, 2015, p. 1053-1062.

50 Em matéria de admissibilidade de testamentos de mão comum, por exemplo [cfr. o artigo $64 .^{\circ}$, alínea $c$ )].

51 Sobre o ponto, e para uma perspectiva geral, cfr. Moura Ramos, R. M. «Linhas Gerais da evolução do direito internacional privado português posteriormente ao Código Civil de 1966", en Estudos 
18. Tal é desde logo verdade no que diz respeito ao acervo de regras aplicáveis, e isto sem embargo de as alterações sofridas por aquelas disposições terem sido muito escassas, limitando-se às até ao presente mencionadas ${ }^{52}$.

19. O certo é que tais soluções legais, sem terem propriamente sido modificadas, têm vindo a ver crescentemente reduzido o campo de aplicação para que as vocacionava o Código Civil. Tal resultou, em primeiro lugar, da circunstância de novas regras de conflitos terem sido incluídas noutras codificações posteriores, limitando o âmbito de aplicação das previstas no Código Civil. Foi o que se passou com o Código dos Direitos de Autor, em 1985 (artigos 37. ${ }^{\circ}$ e 63. ${ }^{\circ}$ a 66..$\left.^{\circ}\right)^{53}$, o Código das Sociedades Comerciais, em 1986 $\left(\text { artigo } 3^{\circ}\right)^{54}$, o Código dos Valores Mobiliários, em 1999 (artigos 3. ${ }^{\circ}, 39 .^{\circ}$ a 42. $.^{\circ}, 108 .^{\circ}, 145 .^{\circ}$ a $148 .^{\circ}, 227 .^{\circ}, 285 .^{\circ}$ e $\left.321 .^{\circ}\right)^{55}$, o Código do Trabalho, em 2003 (artigos 6. ${ }^{\circ}$ a $9 .^{\circ}{ }^{56}$, e $4 .^{\circ}$ a $8 .^{\circ}$, na versão de 2009), e o Código da Propriedade Industrial, nesse mesmo ano (artigos 3. ${ }^{\circ}$ e $\left.4 .^{\circ}\right)^{57}$. A adopção destas regras, cuja inspiração não foi necessariamente a que estivera na base do sistema do Código Civil, reduziu assim claramente o lugar (praticamente de exclusivo) que a este último cabia no direito internacional privado português.

20. E o mesmo aconteceria com a aprovação de leis especiais, que a partir da década de 80 vieram regular certos institutos de direito privado (como as cláusulas contratuais gerais ${ }^{58}$, em 1985, o contrato de agência ou represen-

de Direito Internacional Privado e de Direito Processual Civil Internacional, vol. II, Coimbra, Coimbra Editora, 2007, p. 275-325.

52 Cit. supra, na nota 1.

53 Cfr. Moura Vicente, D., «Direito Internacional de Autor», en Direito Internacional Privado. Ensaios, vol. I, Coimbra, Almedina, 2002, p. 107-143, e Lima PINHEIRo, L., "Algumas considerações sobre a lei aplicável ao direito de autor na Internet», Revista da Ordem dos Advogados, vol. 74, enero-marzo 2014, n. ${ }^{\circ}$ I, p. 13-34.

${ }^{54}$ Cfr. Moura Ramos, R. M., "Aspectos recentes do direito internacional privado português», en Das Relações Privadas Internacionais. Estudos de Direito Internacional Privado, Coimbra, Coimbra Editora, 1995, p. 85-142, esp. p. 108-113; Lima PinHeIro, L., «O Direito Aplicável às Sociedades. Contributo para o Direito Internacional Privado das Sociedades», Revista da Ordem dos Advogados, vol. 58, 1998, II, p. 673-777, e PEREIRA Dias, R., «As Sociedades no Comércio Internacional», Miscelâneas, IDET, n. ${ }^{\circ}$ 5, Coimbra, Almedina, 2008, p. 42-108, esp. p. 60-96.

55 Cfr., a propósito, BRITo, M. H., «Sobre a aplicação no espaço do novo Código dos Valores Mobiliários», en Direito dos Valores Mobiliários, IV, Coimbra, Coimbra Editora, 2003, p. 85-109.

56 Cfr., sobre o ponto, Moura Vicente, D., «O Direito Internacional Privado no Código do Trabalho", en Estudos do Instituto de Direito do Trabalho, Coimbra, Almedina, 2003, p. 15-34, e BRITO, M. E., «Direito aplicável ao contrato internacional de trabalho. Algumas considerações a propósito do Código do Trabalho", en Estudos em Memória do Conselheiro Luís Nunes de Almeida, Coimbra, Coimbra Editora, 2007, p. 105-143.

57 Cfr. o Decreto-Lei n..$^{\circ}$ 36/2003, de 5 de Março e os seus artigos $3 .^{\circ}$ e $4 .^{\circ}$, e, recentemente, o Decreto-Lei . $^{\circ} 110 / 2018$, de 10 de Dezembro.

58 Cfr. o Decreto-Lei n. ${ }^{\circ} 446 / 85$, de 25 de Outubro, e, na sua versão actual (decorrente do Decreto-Lei n. ${ }^{\circ} 323 / 2001$, de 17 de Dezembro) o seu artigo 23. ${ }^{\circ}$ Sobre o ponto, cfr. Moura Ramos, R. M., op. cit., nota 54, p. 99-103 e 106-107; id., "Remarques sur les développements récents du droit international privé portugais en matière de protection des consommateurs", en E Pluribus Unum. Liber Amicorum Georges A. L. Droz. Sur l'unification progressive du droit international privé, Kluwer Law International, 1996, p. 233-251, e $i d$., "La transposition des directives communautaires en matière de protection du consommateur et le droit international privé portugais», en Festschrift fur Erik Jayme, op. cit., nota 22, p. 615-626, e Galvão Teles, E., "A Lei Aplicável aos Contratos de Consumo no Labirinto Comunitário», 
tação comercial ${ }^{59}$, e o estabelecimento mercantil individual de responsabilidade limitada ${ }^{60}$, em 1986, a adopção internacional ${ }^{61}$ e o regime jurídico da habitação periódica ${ }^{62}$, em 1993, o estatuto legal do navio ${ }^{63}$ em 1998, o contrato de seguro ${ }^{64}$ em 2008, e os regimes jurídicos da reparação de acidentes de trabalho e de doenças profissionais ${ }^{65}$, do apadrinhamento civil ${ }^{66}$ e do adulto acompanhado ${ }^{67}$ ) e de direito processual (a arbitragem voluntária, em $1986^{68}$ e, posteriormente, em $2011^{69}$ ), e mesmo matérias de direito público (como a protecção do património cultural) ${ }^{70}$.

21. Mas não foi apenas o legislador interno que contribuiria por esta forma para o desenvolvimento do direito internacional privado português, tendo-se verificado, no período posterior à entrada em vigor do Código Civil, a vinculação, por parte de Portugal, a um número significativo de instrumentos internacionais de carácter convencional. Este contexto de abertura ao direito internacional atingiria de forma particular a nossa disciplina, tendo-se verificado a ratificação por Portugal de um número expressivo de convenções, nomeadamente em matéria de direito dos menores e da família, em particular as negociadas no âmbito da Conferência da Haia de Direito Internacional Privado $^{71}$. E este movimento prosseguiria depois, com a negociação e entra-

en Estudos em Homenagem ao Prof. Doutor Inocêncio Galvão Telles, I Volume - Direito Privado e Vária, Coimbra, Almedina, 2002, p. 683-751.

59 Cfr. o Decreto-Lei n. ${ }^{\circ} 176 / 86$, de 3 de Julho, e o seu artigo $38 .^{\circ}$ Ver também a obra citada em primeiro lugar na nota anterior, p. 93-96.

${ }^{60}$ Cfr. o Decreto-Lei n. ${ }^{\circ}$ 248/86, de 25 de Agosto, e o seu artigo 36. ${ }^{\circ}$ Cfr. Moura Ramos, R. M., op. cit., nota 54, p. 111-112.

${ }^{61}$ Cfr. o Decreto-Lei n. ${ }^{\circ} 185 / 93$, de 22 de Maio, artigos $15 .^{\circ}$ a $27 .^{\circ}$, posteriormente substituídos pelos artigos $14 .^{\circ}$ a $27 .^{\circ}$ do Decreto-Lei n. ${ }^{\circ} 120 / 98$, de 8 de Maio, e pelos artigos $61 .^{\circ}$ a $90 .^{\circ}$ da Lei n. ${ }^{\circ} 143 / 2015$, de 8 de Setembro. Sobre o regime estabelecido pelos dois primeiros diplomas citados, cfr. Moura Ramos, R. M., «Succession et coexistence d'approches et de procédés au fil du temps: l'adoption en droit international privé portugais», en Private Law in the International Arena. From National Conflict Rules towards Harmonization and Unification. Liber Amicorum Kurt Siehr, The Hague, 2000, T. M. C. Asser Press, p. 481-496 (489-493).

${ }^{62}$ Cfr. o Decreto-Lei n. ${ }^{\circ} 275 / 93$, de 5 de Agosto, e posteriormente (nos Decretos-Lei n. ${ }^{\text {os }}$ 180/99, de 22 de Maio, 22/2002, de 31 de Janeiro, e 37/2011, de 10 de Março) o artigo 60. ${ }^{\circ}$ Sobre o regime estabelecido pelos dois primeiros diplomas citados, cfr. Moura RAMOs, R. M., op. cit., nota 58, p. 623-625.

${ }^{63}$ Cfr. o Decreto-Lei n. ${ }^{\circ}$ 201/98, de 10 de Julho, e Lima Pinheiro, L., op. cit., nota 21.

${ }^{64}$ Cfr. o Decreto-Lei n. ${ }^{\circ} 72 / 2008$, de 16 de Abril, e os seus artigos $5 .^{\circ}$ a $10 .^{\circ}$

${ }^{65}$ Cfr. a Lei n. ${ }^{\circ} 98 / 2009$, de 4 de Setembro, e os seus artigos $5 .^{\circ}$ e $6 .^{\circ}$

${ }^{66}$ Cfr. a Lei n. ${ }^{\circ}$ 103/2009, de 11 de Setembro, e o seu artigo 3. ${ }^{\circ}$

67 Cfr. a Lei n. ${ }^{\circ} 49 / 2018$, de 14 de Agosto, e o seu artigo 2. ${ }^{\circ}$

${ }^{68}$ Cfr. a Lei n. ${ }^{\circ} 31 / 86$, de 29 de Agosto, e os seus artigos $32 .^{\circ}$ a $35 .^{\circ}$ A propósito, cfr. Moura Ramos, R. M., op. cit., nota 54, p. 120-123.

${ }^{69}$ Com a lei aprovada pela Lei n. ${ }^{\circ}$ 63/2011, de 14 de Dezembro, artigos $49 .^{\circ}$ a $54 .^{\circ}$ Cfr. MourA RAMos, R. M., «L'arbitrage international dans le nouveau droit portugais de l'arbitrage», en Entre Bruselas y La Haya. Estudios sobre la unificación internacional y regional del Derecho Internacional Privado. Liber amicorum Alegria Borràs, Madrid, Marcial Pons, 2013, p. 611-624.

70 Cfr. a Lei n. ${ }^{\circ} 107 / 2001$, de 8 de Setembro, e o seu artigo 69. ${ }^{\circ}$

71 Sobre esta questão, cfr. Moura Ramos, R. M., "A Conferência da Haia de Direito Internacional Privado: A participação de Portugal e o papel da organização na codificação internacional do direito internacional privado», en España y la codificación internacional del Derecho internacional privado, Madrid, Eurolex, 1993, p. 17-40, esp. p. 31-36. 
da em vigor de tratados bilaterais ${ }^{72}$, e, mais tarde, com a adesão a textos cuja vinculação decorria das obrigações assumidas no âmbito da participação portuguesa nas Comunidades e na União Europeias ${ }^{73}$.

22. Não foi no entanto apenas no direito interno e no direito internacional convencional que se deu o desenvolvimento do direito internacional privado português, podendo dizer-se que tal movimento viria a ser igualmente desencadeado pela influência do direito comunitário.

23. Para além do que já ficou dito ${ }^{74}$, dois pontos interessa sobremaneira mencionar. Em primeiro lugar, por via indirecta, digamos, através dos actos de transposição de directivas. Tal aconteceu, por exemplo, em matéria de cláusulas abusivas nos contratos celebrados pelos consumidores ${ }^{75}$, de contratos de timesharing ${ }^{76}$, de protecção jurídica de programas de computador $^{77}$, de protecção de dados pessoais ${ }^{78}$, de protecção jurídica das bases

72 Como a Convenção luso-francesa de cooperação judiciária relativa à protecção de menores, assinada a 20 de Julho de 1983, e a Convenção luso-luxemburguesa relativa ao auxílio judiciário em matéria de direito de guarda e de direito de visita, de 12 de Junho de 1992.

73 Estamos a pensar sobretudo na Convenção de Roma de 19 de Junho de 1980, sobre a lei aplicável às obrigações contratuais, a que o nosso país se vinculou através da Convenção de adesão assinada no Funchal, em 18 de Maio de 1992.

74 Veja-se a nota anterior. Para um balanço correspondente, no que diz respeito ao direito espanhol, cfr. Borrás, A., «30 Años de España en la Unión Europea: Su significado en el ámbito del Derecho Internacional Privado», Anuario Español de Derecho Internacional Privado, vol. 16, 2016, p. 35-41.

75 Directiva 93/13/CEE do Conselho, de 5 de Abril de 1993, relativa às cláusulas abusivas nos contratos celebrados com os consumidores. Cfr. o Decreto-Lei n. ${ }^{\circ} 249 / 99$, de 7 de Dezembro, e a obra citada supra, em penúltimo lugar, na nota 58, p. 622-623, e, na nossa doutrina, PINTO MoNTEIRO, F., «La directive "clauses abusives", 5 ans après - A transposição para a ordem jurídica interna da Directiva 93/13/CEE», Boletim da Faculdade de Direito, vol. 75, 1999, p. 523-536, e OliveIRA AscENSÃo, J, "Cláusulas contratuais gerais, cláusulas abusivas e boa fé», Revista da Ordem dos Advogados, vol. 60, 2000, p. 573-595.

Em matéria de protecção dos consumidores, vejam-se ainda as Directivas 85/577/CEE, do Conselho, de 20 de Dezembro de 1985, relativa à protecção dos consumidores no caso de contratos negociados fora dos estabelecimentos comerciais, e 97/7/CE, do Parlamento Europeu e do Conselho, de 20 de Maio de 1997, relativa à protecção dos consumidores em matéria de contratos à distância, posteriormente revogadas pela Directiva 2011/83/UE, do Parlamento Europeu e do Conselho, de 25 de Outubro de 2011, relativa aos direitos dos consumidores, e que altera o acto inicialmente citado assim como o referido infra, na nota 80 . Sobre este último acto, transposto entre nós pelo Decreto-Lei n. ${ }^{\circ}$ 24/2014, de 14 de Fevereiro, cfr. Pinto Monteiro, F., «O novo regime da contratação à distância: breve apresentação», in Estudos de Direito do Consumidor, vol. 9 (2015), p. 11-18, Mota PINTo, P., "O novo regime jurídico dos contratos à distância e dos contratos celebrados fora do estabelecimento comercial», $i b i$ dem, p. 51-92, e Passinhas, S. «A Directiva 2011/83/UE, do Parlamento Europeu e do Conselho, de 25 de Outubro de 2011, relativa aos direitos dos consumidores: algumas considerações», ibid., p. 93-140.

76 Directiva 94/47/CE, do Parlamento Europeu e do Conselho, de 26 de Outubro de 1994, relativa à protecção dos adquirentes quanto a certos aspectos dos contratos de aquisição de um direito de utilização a tempo parcial de bens imóveis. Cfr. o Decreto-Lei n. ${ }^{\circ} 22 / 2002$, de 31 de Janeiro, e a obra citada supra, na nota 62.

77 Directiva 91/250/CEE do Conselho, de 14 de Maio de 1991, relativa à protecção jurídica dos programas de computador. Cfr. o Decreto-Lei n. ${ }^{\circ}$ 252/94, de 20 de Outubro, e o seu artigo $17 .^{\circ}$

78 Directiva 95/46/CE do Parlamento Europeu e do Conselho, de 24 de Outubro de 1995, relativa à protecção das pessoas singulares no que diz respeito ao tratamento de dados pessoais e à livre circulação desses dados. Cfr. a Lei n. ${ }^{\circ} 67 / 98$, de 26 de Outubro, e os seus artigos $4 .^{\circ}$ e $18 .^{\circ}$ a $19 .^{\circ}$ Este texto seria entretanto revogado pelo Regulamento (UE) 2016/679, do Parlamento Europeu e do Conselho, de 27 de Abril de 2016, relativo à protecção das pessoas singulares no que diz respeito ao tratamento de dados 
de dados ${ }^{79}$, de certos aspectos da venda de bens de consumo e das garantias a ela relativas ${ }^{80}$, de certos aspectos legais dos serviços da sociedade da informação, em especial do comércio electrónico, no mercado interno ${ }^{81}$, do regime jurídico dos contratos de garantia financeira ${ }^{82}$, dos contratos à distância relativos a serviços financeiros celebrados com consumidores ${ }^{83}$, do saneamento e liquidação de instituições de crédito ${ }^{84}$, e de fusões transfronteiriças ${ }^{85}$. Em todos estes domínios, na verdade, o direito português passou, por força da transposição de directivas comunitárias, a incluir as regras de direito internacional privado previstas naqueles actos unilaterais das Comunidades ou da União Europeias.

24. Em segundo lugar, e agora mais decisivamente, por força da criação de um direito internacional privado da União Europeia ${ }^{86}$, que se de-

pessoais e à livre circulação desses dados (cfr. artigo 94. ${ }^{\circ}$ deste último texto), revogação que produziu efeitos na data de aplicação daquele acto, isto é, nos termos do seu artigo $99 .^{\circ}$, n. ${ }^{\circ}$ 2, a partir de 25 de Maio de 2018.

79 Directiva 96/9/CE do Parlamento Europeu e do Conselho, de 11 de Março de 1996, relativa à protecção jurídica das bases de dados. Cfr. o Decreto-Lei n. ${ }^{\circ} 122 / 2000$, de 4 de Julho, e os seus artigos 2 . $^{\circ}$ e 3 . $^{\circ}$

80 Directiva 1999/44/CE do Parlamento Europeu e do Conselho, de 25 de Maio de 1999, relativa a certos aspectos da venda de bens de consumo e das garantias a ela relativas. Cfr. o Decreto-Lei n. ${ }^{\circ}$ 67/2003, de 25 de Maio, e o seu artigo $11 .^{\circ}$, e, na nossa doutrina, Moura VicENTE, D., "Desconformidade e garantias na venda de bens de consumo: A directiva 1999/44/CE e a Convenção de Viena de 1980», en op. cit., nota 53, p. 35-58, МотA PINTo, P., "Conformidade e garantias na venda de bens de consumo. A Directiva 1999/44/CE e o direito português», Estudos de Direito do Consumidor, vol. 2, 2000, p. 197-331, e Menezes LeItão, L., «Caveat Venditor? A Directiva 99/44/CE do Conselho e do Parlamento Europeu sobre a venda de bens de consumo e garantias associadas e suas implicações no regime jurídico da compra e venda», en op. cit., nota 58, p. 263-303.

${ }_{81}$ Directiva 2000/31/CE do Parlamento Europeu e do Conselho de 8 de Junho de 2000 relativa a certos aspectos legais dos serviços da sociedade de informação, em especial do comércio electrónico, no mercado interno ( (Directiva sobre o comércio electrónico»). Cfr. o Decreto-Lei n. ${ }^{\circ}$ 7/2004, de 7 de Janeiro, e os seus artigos $4 .^{\circ}$ a $8 .^{\circ}$, e, na doutrina portuguesa, CAlvão da Silva, J., Banca, Bolsa e Seguros.

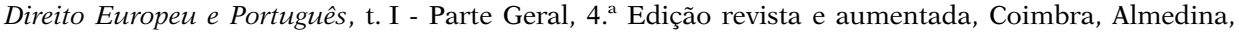
2013, p. 129-146; Dias PEREIRA, A., «A protecção do consumidor no quadro da Directiva sobre o comércio electrónico», Estudos de Direito do Consumidor, vol. 2, 2000, p. 43-140, e Moura VicENTE, D., «A comunitarização do direito internacional privado e o comércio electrónico», en Direito Internacional Privado. Ensaios, vol. II, Coimbra, Almedina, 2005, p. 171-185.

${ }^{82}$ Directiva 2002/47/CE do Parlamento Europeu e do Conselho, de 6 de Junho de 2002, relativa aos acordos de garantia financeira. Cfr. o Decreto-Lei n. ${ }^{\circ} 105 / 2004$, de 8 de Maio, e o seu artigo $21 .^{\circ}$

83 Directiva 2002/65/CE do Parlamento Europeu e do Conselho, de 23 de Setembro de 2002, relativa à comercialização à distância de serviços financeiros prestados a consumidores. Cfr. o Decreto-Lei n. ${ }^{\circ}$ 95/2006, de 29 de Maio, e o seu artigo $40 .^{\circ}$

${ }^{84}$ Directiva 2001/24/CE do Parlamento Europeu e do Conselho de 4 de Abril de 2001, relativa ao saneamento e à liquidação das instituições de crédito. Cfr. o Decreto-Lei n. ${ }^{\circ}$ 199/2006, de 25 de Outubro. Estes dois textos seriam entretanto modificados, respectivamente, pela Directiva 2014/59/UE, do Parlamento Europeu e do Conselho, de 15 de Maio de 2014, que estabelece um enquadramento para a recuperação e a resolução de instituições de crédito e de empresas de investimento, e pelo Decreto-Lei n. ${ }^{\circ}$ 31-A/2012, de 10 de Fevereiro.

85 Directiva 2005/56/CE do Parlamento Europeu e do Conselho, de 26 de Outubro de 2005, relativa às fusões transfronteiriças das sociedades de responsabilidade limitada, e Directiva 2007/63/CE do Parlamento Europeu e do Conselho, de 13 de Novembro de 2007, que altera as Directivas 78/855/CEE e 82/891/CEE do Conselho no que respeita à exigência de um relatório de peritos independentes aquando da fusão ou da cisão de sociedades anónimas. Cfr. a Lei n. ${ }^{\circ}$ 19/2009, de 12 de Maio.

${ }^{86}$ Sobre a questão, cfr. Moura Ramos, R. M., Estudos de Direito Internacional Privado da União Europeia, Coimbra, 2016, Imprensa da Universidade de Coimbra. Cfr. ainda Bogdan, M., Concise Intro- 
senvolveu, já neste século, através de regulamentos, e que nos domínios que nos importam, por serem os que se reportam às matérias de direito internacional privado constantes do Código Civil, envolveu já a aprovação de actos relativos à lei aplicável às obrigações extracontratuais ${ }^{87}$, às obrigações contratuais ${ }^{88}$, às obrigações alimentares ${ }^{89}$, ao divórcio ${ }^{90}$, às sucessões por morte ${ }^{91}$, e aos efeitos patrimoniais, do casamento ${ }^{92}$ como das uniões

duction to EU Private International Law, 3rd edition, Groningen, Europa Law Publishing, 2016; «The Communitarisation of Private International Law» (contribuições de BASEdow, J., von HeIN, J., PAUL Beaumont, P., Anatol Dutta, A., Kieninger E. M. e Bariatti, S.), RabelsZ, 73 (2009), p. 455-664, ReICHelt, G. e Rechberger, W. H. (Hrsg), Europaisches Kollisionsrecht. Anwendbares Recht, Gerichtliche Zustandigkeit, Vollstreckung von Entscheidungen im Binnenmarkt, Wien, 2004, Manz; FALlON, M., KINSCH, P. e KoHLer, C. (eds), Le Droit International Privé Européen en construction. Vingt Ans de travaux du GEDIP, Cambridge, Intersentia, 2011; Fallon, M., Lagarde, P. e Poilllot-Peruzzetto, S. (dirs.), Quelle architecture pour un code européen de droit international privé?, Bruxelles, Peter Lang, 2011; VAN CALSTER, G., European Private International Law, Second Edition, Oxford, Hart Publishing, 2016; Grundfragen des Europäischen Kollisionsrechts (herausgegeben von Stefan Arnold), Tübingen, Mohr Siebeck, 2016; LeIBle, S. (ed.), General Principles of European Private International Law, Alphen an den Rijn, Kluwer Law International, 2016, e BRITo, M. H., Direito Internacional Privado sob Influência do Direito Europeu, Lisboa, Âncora Editora, 2017.

${ }^{87}$ Cfr. o Regulamento (CE) n. ${ }^{\circ} 864 / 2007$, do Parlamento e do Conselho, de 11 de Julho de 2007, relativo à lei aplicável às obrigações extracontratuais (Roma II). MouRA RAMOS, R. M., «O direito internacional privado das obrigações extracontratuais na União Europeia», en op. cit., nota 86, p. 109-144; Lima Pinheiro, L., Direito Internacional Privado, vol. II - Direito de Conflitos - Parte Especial, 4. ${ }^{a}$ Edição Refundida, Coimbra, Almedina, 2015, p. 471-511, e MoitinHo DE AlmEIDA, J. C., O Regulamento Roma II. Lei Aplicável às Obrigações Extracontratuais, Cascais, Principia, 2017.

${ }^{88}$ Cfr. o Regulamento (CE) n. ${ }^{\circ}$ 593/2008, do Parlamento Europeu e do Conselho, de 17 de Junho de 2008, sobre a lei aplicável às obrigações contratuais (Roma I); Moura RAMOS, R. M., «O direito internacional privado das obrigações contratuais na União Europeia», en op. cit., nota 86, p. 73-107, e LIMA PINHEIRO, L., op. cit., nota 87, p. 314-410.

${ }^{89}$ Cfr. o Regulamento (CE) n. ${ }^{\circ} 4 / 2009$, do Conselho, de 18 de Dezembro de 2008, relativo à competência, à lei aplicável, ao reconhecimento e à execução das decisões e à cooperação em matéria de obrigações alimentares; Moura Ramos, R. M., "As obrigações alimentares no direito internacional privado da União Europeia», en op. cit., nota 86, p. 145-182; LIMA PINHEIRo, op. cit., nota 87, p. 124-138, e Rocha RibeIRo, G., «A obrigação de alimentos devidos a menores nas relações transfronteiriças. Uma primeira abordagem ao Regulamento (CE) n. ${ }^{\circ}$ 4/2009 e ao Protocolo da Haia de 2007 ", Lex Familiae, vol. 10 , n. 20,2013 , p. 83-114.

${ }_{90}$ Cfr. o Regulamento (UE) n. ${ }^{\circ}$ 1259/2010, do Conselho, de 20 de Dezembro de 2010, que cria uma cooperação reforçada no domínio da lei aplicável em matéria de divórcio e separação judicial; MouRA Ramos, R. M., «Um novo regime do divórcio internacional na União Europeia», en op. cit., nota 86, p. 163-236; Lima Pinheiro, L., op. cit., nota 87, p. 658-669, e Gomes De Almeida, J., O Divórcio em Direito Internacional Privado, Coimbra, Almedina, 2017, p. 273-479.

${ }_{91}$ Cfr. o Regulamento (UE) n. ${ }^{\circ}$ 650/2012, do Parlamento Europeu e do Conselho, de 4 de Julho de 2012, relativo à competência, à lei aplicável, ao reconhecimento e execução das decisões, e à aceitação e execução dos actos autênticos em matéria de sucessões e à criação de um certificado sucessório europeu; Moura Ramos, R. M., "O direito internacional privado das sucessões na União Europeia», en op. cit., supra, nota 86, p. 237-286; LIMA PINHEIRO, L., op. cit., supra, nota 87, p. 686-697; AsCENSÃO SILVA, N., "A sucessão testamentária no direito internacional privado - Desenvolvimentos recentes", Cadernos do C.E.No.R. Centro de Estudos Notariais e Registais, vol. 4, 2016, p. 119-215, esp. p. 134-215, em diálogo com o sistema português de fonte autónoma), e DAVI, A. e ZANOBETTI, A., Il nuovo diritto internazionale privato europeo delle successioni, Torino, G. Giappichelli Editore, 2014.

92 Cfr. o Regulamento (UE) n. ${ }^{\circ}$ 2016/1103, do Conselho, de 24 de Junho de 2016, que implementa a cooperação reforçada no domínio da competência, da lei aplicável, do reconhecimento e da execução de decisões em matéria de regimes matrimoniais. Sobre este texto e o citado na nota seguinte, cfr. FERNÁNDEZ RozAs, J. C., «Un hito más en la comunitarización del derecho internacional privado: regímenes económicos matrimoniales y efectos patrimoniales de las uniones registradas», La Ley. Unión 
registadas ${ }^{93}$. Para além de, por força das características do direito da União, os preceitos do Código Civil nesta matéria se terem tornado de aplicação residual, deve ainda sublinhar-se que as próprias regras da parte geral do Código sofrem limites na sua aplicação, uma vez que aqueles actos de direito da União contém regras próprias sobre as questões da parte geral ${ }^{94}$, que nem sempre coincidem com as primeiras e que, naturalmente, afastam a sua aplicação.

25. Independentemente de o corpo de normas relativas ao direito internacional privado resultar assim sobremaneira alterado, deve ainda ter-se presente que as novas regras que acabámos de referir apresentam por vezes algumas diferenças, na sua construção, face às anteriores. Assim, se é certo que continuamos a lidar apenas com regras de conflitos bilaterais, sendo que as situações em que a sua aplicação é limitada são as mesmas que já encontrávamos no Código Civil ${ }^{95}$, o respeito pelo princípio da paridade de tratamento surge menos vincado, sendo admitido em maior medida o recurso directo, ainda que em via subsidiária, à lex fori ${ }^{96}$. É certo que a este recurso à lex fori não é em muitos casos estranha a preocupação de garantir certos resultados materiais, mas é igualmente verdade que aumenta assim o número de regras em que o legislador se orienta por preocupações de justiça material, e em que a regra de conflitos deixa portanto de cumprir uma função puramente localizadora ${ }^{97}$. Por outro lado, acentua-se a flexibilização das regras de conflitos, nomeadamente pelo recurso a cláusulas de excepção ${ }^{98}$, e alarga-se o recurso ao princípio da autonomia das partes, que passa a ser admitido também fora

Europea, vol. 40, septiembre 2016, p. 1-29, e, entre nós, Moura RAMOs, R. M., «Os efeitos patrimoniais do casamento e das parcerias registadas no direito internacional privado da União Europeia», Boletim da Faculdade de Direito, vol. XCIII (2017), t. I, p. 1-55, е МотА, H., «Os efeitos patrimoniais do casamento e das uniões de facto registadas no Direito Internacional Privado da União Europeia. Breve análise dos Regulamentos (UE) 2016/1103 e 2016/1104, de 24 de Junho», Revista Electrónica de Direito, n. ${ }^{\circ} 2$, 2017, p. 1-33.

93 Cfr. o Regulamento (UE) n. ${ }^{\circ}$ 2016/1104, do Conselho, de 24 de Junho de 2016, que implementa a cooperação reforçada no domínio da competência, da lei aplicável, do reconhecimento e da execução de decisões em matéria de efeitos patrimoniais das parcerias registadas, e Moura RAMOS, R. M., "Similitudes et disparités dans les instruments de droit international privé de l'union européenne relatifs aux effets patrimoniaux du mariage et des partenariats enregistrés», en HESS, B., JAYME, E. e MANSEL, H.-P. (eds.), Europa Als Rechts- und Lebensraum. Liber Amicorum fur Christian Kohler zum 75. Geburtstag, Bielefeld, Gieseking Verlag, 2018, p. 347-356.

94 Cfr. os trabalhos mencionados supra, nas notas 87 a 92.

95 Cfr. o artigo $13 .^{\circ}$ do Regulamento Roma I.

96 Cfr. o artigo 4. ${ }^{\circ}$, n. $^{\text {os }} 2$ e 3 do Protocolo da Haia de 2007, sobre a lei aplicável às obrigações de alimentos, para que remete o artigo $15 .^{\circ}$ do Regulamento n. $.^{\circ} 4 / 2009$, o artigo 5. ${ }^{\circ}$, n. ${ }^{\circ} 1$, alínea a), o artigo $8 .^{\circ}$, alínea d), e o artigo $10 .^{\circ}$ do Regulamento n. ${ }^{\circ} 1259 / 2010$.

97 Assim, os artigos $6 .^{\circ}$ e $80^{\circ}$ do Regulamento Roma I, relativos a contratos (certos contratos celebrados com consumidores e o contrato de trabalho) em que avulta a preocupação com a protecção da parte mais débil, o artigo $4 .^{\circ}$ do Protocolo da Haia de 2007, sobre a lei aplicável às obrigações de alimentos, para que remete o artigo $15 .^{\circ}$ do Regulamento n. ${ }^{\circ} 4 / 2009$, e o artigo $10 .^{\circ}$ do Regulamento n. ${ }^{\circ} 1259 / 2010$

98 Cfr. os artigos $4 .^{\circ}$, n. $^{\circ} 3,5 .^{\circ},{ }^{\circ} 3,7 .^{\circ}$, n..$^{\circ} 2$, segunda frase, e $8 .^{\circ}$, n. ${ }^{\circ} 4$, do Regulamento Roma I, 4..$^{\circ}$ n. $.^{\circ} 3,5 .^{\circ}$, n. ${ }^{\circ} 2,10 .^{\circ},{ }^{\circ} 4$ e $11 .^{\circ}$, n. ${ }^{\circ} 4$ do Regulamento Roma II, o artigo 5. ${ }^{\circ}$ do Protocolo da Haia de 2007 , sobre a lei aplicável às obrigações de alimentos, para que remete o artigo $15 .^{\circ}$ do Regulamento n. ${ }^{\circ} 4 / 2009$, e o artigo $21 .^{\circ},{ }^{\circ}{ }^{\circ} 2$, do Regulamento n. ${ }^{\circ} 650 / 2012$. 
do domínio contratual ${ }^{99}$. E o sistema passa além disso a prever expressamente a aplicação das normas internacionalmente imperativas da lex fori ${ }^{100}$ (bem como a tomada em consideração das regras do mesmo tipo contidas em leis estrangeiras $\left.{ }^{101}\right)^{102}$.

26. Se pretendermos agora comparar o sistema de direito internacional privado hoje vigente em Portugal com o que resultou da entrada em vigor do Código de 1966, o traço mais saliente que avulta nesse confronto talvez seja, para além da pluralidade de fontes que contrasta com a unidade de regulamentação que o Código Civil propiciava, a especialização do sistema da parte especial dele resultante. Especialização que se patenteia sobretudo em matéria de obrigações, quer contratuais (com a disciplina prevista para diversas categorias, como o contrato de transporte, certos contratos celebrados por consumidores, o contrato de seguro, o contrato individual de trabalho, para além da previsão específica da lei aplicável em várias outras situações em que as partes não hajam feito uso da possibilidade de escolha da lei) ${ }^{103}$, quer extracontratuais (com a previsão de uma disciplina própria ${ }^{104}$ para a responsabilidade por produtos defeituosos, a concorrência desleal e os actos que restrinjam a livre concorrência, os danos ambientais, a violação de direitos de propriedade intelectual e as acções colectivas), quer nas obrigações alimentares, e que prolonga a tendência iniciada pelo Código Civil em relação ao Código de Seabra ${ }^{105}$, e que se impôs igualmente no direito

99 Cfr. os artigos $3 .^{\circ}, 6 .^{\circ}$, n. ${ }^{\circ} 2,7 .^{\circ}$, n..$^{\text {os }} 2$ e $3,8^{\circ}$, n. $^{\circ} 1$, do Regulamento Roma I, o artigo $14 .^{\circ}$ (limitado pelos artigos $6 .^{\circ}$, n. $^{\circ} 4$, e $8 .^{\circ}$, n..$^{\circ}$ ) do Regulamento Roma II, os artigos $7 .^{\circ}$ e $8 .^{\circ}$ do Protocolo da Haia de 2007, sobre a lei aplicável às obrigações de alimentos, para que remete o artigo $15 .^{\circ}$ do Regulamento n. ${ }^{\circ} 4 / 2009$, o artigo $5 .^{\circ}$ do Regulamento n. ${ }^{\circ} 1259 / 2010$, os artigos $22 .^{\circ}, 24 .^{\circ}$, n. ${ }^{\circ} 2$, e $25 .^{\circ}$, n. ${ }^{\circ} 3$, do Regulamento.$^{\circ}$ 650/2012, e o artigo 22. ${ }^{\circ}$, tanto do Regulamento n. ${ }^{\circ}$ 2016/1103 como do Regulamento 2016/1104.

100 Cfr. os artigos 9. ${ }^{\circ}, \mathrm{n} .^{\circ} 2$, do Regulamento Roma I, $16 .^{\circ}$ do Regulamento Roma II, e $30 .^{\circ}$, n. $^{\circ} 1$, tanto do Regulamento n. ${ }^{\circ}$ 2016/1103 como do Regulamento 2016/1104.

101 Cfr. os artigos 9. ${ }^{\circ}$ n. ${ }^{\circ}$, do Regulamento Roma I, e 17. ${ }^{\circ}$ do Regulamento Roma II.

102 Para uma caracterização das orientações fundamentais do nosso sistema, cfr. Moura RAMOs, R. M., «Le Droit international privé portugais à la fin du vingtième siècle: progrès ou recul?», en SYMEONIDES, S. (ed.), Private International Law at the End of the 20th Century: Progress or Regress?, London, Kluwer Law International, 2000, p. 349-382, esp. p. 352-365, e LIMA PINHEIRo, L., «Algumas reflexões sobre a codificação portuguesa do direito internacional privado», en Estudos em Homenagem ao Prof. Doutor Sérvulo Correia, vol. III, Coimbra, Coimbra Editora, 2010, p. 743-768, esp. p. 745-753. E no sentido da sua consonância com as orientações seguidas no plano do direito comparado, cfr. MouRA Ramos, R. M., "Perspectiva do Direito Internacional Privado no limiar do novo século», en Internacionalização do Direito no Novo Século (Stvdia Iuridica, 94. Colloquia - 17), Coimbra, Coimbra Editora, 1999, p. 127-144.

${ }_{103}$ Cfr. as distintas hipóteses (compra e venda, prestação de serviços, franquia, distribuição, compra e venda de mercadorias em hasta pública, situações em que o objecto é um direito real sobre um bem imóvel ou o arrendamento de um bem imóvel ou certos instrumentos financeiros) previstas no n. ${ }^{\circ} 1$ do artigo $4 .^{\circ}$ do Regulamento Roma I.

104 Prevista, respectivamente, nos artigos 5. a 9. ${ }^{\circ}$ do Regulamento Roma II.

105 Com a previsão da disciplina conflitual específica quer da gestão de negócios e do enriquecimento sem causa, em matéria obrigacional, quer das várias hipóteses de representação e da prescrição e da caducidade, em sede de negócio jurídico, quer do casamento (como acto, quanto à substância e quanto à forma, e como estado, e aqui, em sede de efeitos pessoais e de efeitos patrimoniais), e da filiação (biológica e adoptiva, e aqui também tanto do estabelecimento como dos efeitos), em sede de relações de família, e, no domínio das sucessões, da sucessão, legal e da voluntária. 
comparado e em numerosas convenções da Conferência da Haia ${ }^{106}$. Depois, há a referir a preocupação com a constitucionalização do sistema, fazendo repercutir os princípios e regras constitucionais nas categorias de conexão previstas pelas regras de conflitos ${ }^{107}$. E, no que toca ao desenho das regras de conflitos, pode dizer-se que se acentuaram, quer a sua materialização ${ }^{108}$, quer a sua flexibilização ${ }^{109}$, do mesmo modo que se viu bastante reforçada tanto a utilização complementar de novas metodologias, como a da regulação directa ou material das situações plurilocalizadas ${ }^{110}$ e a das normas de aplicação necessária e imediata ${ }^{111}$, como o relevo do princípio da autonomia das partes ${ }^{112}$.

\section{A CODIFICAÇÃO DO DIREITO INTERNACIONAL PRIVADO PORTUGUÊS, NO FUTURO}

27. Em temos que podem parecer surpreendentes, cremos decorrer da exposição anterior que se o direito internacional privado vigente em Portugal é hoje bem diverso daquele que resultou da entrada em vigor do Código Civil de 1966, as suas linhas de força essenciais não constituem uma ruptura com os paradigmas que presidiram a esta codificação, decorrendo antes de uma evolução previsível destes últimos. Alcançado este estádio da reflexão que nos propuséramos, importa agora questionarmo-nos sobre o futuro da codificação do direito internacional privado em Portugal. É o que faremos de forma muito sucinta, limitando-nos a adiantar algumas pistas da nossa reflexão pessoal sobre este ponto.

106 A este respeito, cfr. Moura Ramos, R. M., «The impact of the Hague Conventions on Portuguese Private International Law», en The Influence of the Hague Conference on Private International Law, Dordrecht, Martinus Nijhoff Publishers, 1993, p. 79-92, esp. p. 88-89. Sublinhando o carácter mais geral desta tendência, ainda que apenas no domínio do direito da família, cfr. Moura Ramos, R. M., «La evolución reciente del derecho internacional privado de familia en los Estados miembros de la Unión Europea», en Moura Ramos, R. M. e Rodríguez Benot, A., Evolución reciente del derecho internacional privado de familia en los Estados miembros de la Unión Europea, Madrid, Fundación Coloquio Jurídico Europeo, 2016, p. 11-103.

107 Cfr. supra, nota 1, e Moura Ramos, R. M.. "Linhas Gerais da evolução do direito internacional privado português posteriormente ao Código Civil de 1966», en op. cit., nota 51, p. 275-325, esp. p. 305-309, e, agora com um alcance mais geral ainda que limitado às relações de família, id., op. cit., nota 106 , p. $30-39$.

108 Cfr. Moura Ramos, R. M., op. cit., nota 51, p. 316-317, e op. cit., nota 106, p. 69-70.

109 Assim Moura Ramos, R. M., op. cit., nota 106, p. 86-88; Moura Ramos, R. M., op. cit., nota 51, p. 318-319, e Moura Ramos, R. M., op. cit., nota 106, p. 68-69.

110 Assim Moura Ramos, R. M., op. cit., nota 51, p. 310-312.

111 Cfr. Moura Ramos, R. M., op. cit., nota 51, p. 312-315, e Moura Ramos, R. M., op. cit., nota 106, p. $72-74$.

112 Cfr. Moura Ramos, R. M., op. cit., nota 106, p. 85-86; Mills, A., Party Autonomy in Private International Law, Cambridge, Cambridge University Presss, 2018, e, no domínio das relações familiares, Moura Ramos, R. M., op. cit., nota 106, p. 89-93; Panet, A., Fulchiron, H. e Wautelet, P. (eds.), L'autonomie de la volonté dans les relations familiales internationales, Bruxelles, Bruylant, 2017, e KoHLER, C., "Anmerkungen zur Parteiautonomie im internationalen Familien und Erbrecht», en GeBAUER, M., Mansel, H.-P. e Schulze, G. (dirs.), Die Person im Internationalen Privatrecht. Liber Amicorum Erik Jayme, Tubingen, Mohr Siebeck, 2019, p. 9-26. 
28. A este propósito, a convicção mais firme que temos, e mau grado tal representar uma alteração de rumo face às duas codificações do nosso direito privado, é a de que o corpus normativo em que se analisa a codificação do direito internacional privado não deverá num futuro mais ou menos longínquo constar do Código Civil, passando antes a figurar num diploma próprio, uma Lei ou Código de Direito Internacional Privado Português. Tal resulta, nomeadamente, de as questões que tal codificação deverá enfrentar ultrapassarem o mero problema da designação da lei aplicável, que era aquele a que respondeu, de forma particularmente conseguida no momento histórico em que o fez, o Código de 1966, para compreenderem igualmente as regras pertinentes de competência internacional e de reconhecimento das sentenças estrangeiras. Isto pela concepção que fazemos do direito internacional privado e da sua ciência global, que não pode deixar de incluir aquelas duas matérias, sendo que o seu tratamento normativo deverá por isso ser visto em termos integrados. Trata-se aliás de uma orientação que corresponde a uma visão global da nossa disciplina que se tem vindo a impor no plano da discussão metodológica ${ }^{113}$, que tem sido largamente acolhida no direito comparado ${ }^{114}$, que tem encontrado defensores na nossa doutrina ${ }^{115}$, e que seguimos em trabalhos anteriores em que tratámos de institutos da parte especial do direito internacional privado ${ }^{116}$.

29. Ultrapassado o estádio do âmbito material (e, consequentemente, da localização) da regulação autónoma, de fonte nacional, pertinente ao direito internacional privado, deverá em seguida reconhecer-se que, no presente momento, esta não poderá deixar de ter um âmbito acentuadamente mais restrito, dada a natureza residual que há hoje que reconhecer, nos EstadosMembros da União Europeia, à iniciativa do legislador estadual. Na verdade, como resulta das considerações anteriores, o legislador da União chamou a si parte significativa da regulação internacionalprivatística das matérias

113 Cfr., por exemplo, os trabalhos de Picone, P., «La méthode de la référence à l'ordre juridique compétent en droit international privé», Recueil des Cours, t. 197, 1986-II, p. 231-419; id., Ordinamento Competente e Diritto Internazionale Privato, Padova, Cedam, 1986; id., "Les méthodes de coordination entre ordres juridiques en droit international privé. Cours général de droit international privé», Recueil des Cours, t. 276, 1999, p. 11-296, esp. p. 119-142; id., La Riforma Italiana del Diritto Internazionale Privato, Padova, Cedam, 1998, p. 3-53 e 477-514, e id., "Diritto internazionale privato comunitario e pluralità dei metodi di coordinamento tra ordinamenti», en $i d$. (ed.), Diritto Internazionale Privato $e$ Diritto Comunitário, Padova, Cedam, 2004, p. 485-525. Mas a tendência a que nos referimos mobiliza muitos outros autores; cfr., por exemplo, MANKOWSKI, P., «Uber den Standort des Internationalen Zivilprozessrechts. Zwischen Internationalem Privatrecht und Zivilprozessrecht», RabelsZ, vol. 82, 2018, p. 576-617.

114 Cfr. os elementos referidos supra, na nota 3.

115 Assim Lima Pinheiro, L., op, cit. nota 2; id., «Um Direito Internacional Privado para o Século XXI. Relatório", Revista da Faculdade de Direito da Universidade de Lisboa, 2001, Suplemento, p. 21-27; BRITo, M. H., "O direito internacional privado no Código Civil - Perspectivas de Reforma», en Estudos Comemorativos dos 10 Anos da Faculdade de Direito da Universidade Nova de Lisboa, vol. II, Coimbra, Almedina, 2008, p. 355-380, esp. p. 379, e, mais recentemente, GoMES DE ALMEIDA, J., op. cit., nota 90.

116 Cfr. Moura Ramos, R. M., "Portugal», en "L’Adoption dans les principales législations européennes (Étude de droit interne et de droit international privé)», Revue Internationale de Droit Comparé, vol. 37, 1985, p. 845-864. 
a que o Código Civil se dedicara (em sede de obrigações, contratuais, extracontratuais e alimentares, consequências patrimoniais do casamento e da união registada, divórcio e sucessão ${ }^{117}$ ), encontrando-se por isso o nosso legislador (como os dos demais Estados-Membros) impedido de legislar nesses domínios, a não ser quanto às matérias que expressamente tenham ficado fora das regras objecto de uniformização ${ }^{118}$. E uma vez que as regras uniformizadas são de aplicação universal ${ }^{119}$, elas aplicam-se a todas as situações plurilocalizadas não excluídas do seu âmbito material de aplicação, o que impede qualquer possibilidade de exercício da competência estadual nesta matéria. Nestes termos, a iniciativa do legislador estadual, a existir ${ }^{120}$, deverá ser coordenada com a criação normativa levada a cabo no âmbito do direito da União.

30. A este respeito, recorde-se que, se quanto à parte especial são diversos os domínios em que o legislador da União já agiu, também em sede de parte geral, muito embora não exista um texto que directamente verse estas questões ${ }^{121}$, elas não deixaram de ser abordadas no contexto da regulamentação das matérias da parte especial ${ }^{122}$. O que obriga o legislador estadual a ter alguma cautela no exercício dos seus poderes de criação normativa.

117 Cfr. Moura Ramos, R. M., op. cit., nota 86, p. 73-286.

118 É o que se passa, por exemplo, em matéria de obrigações extracontratuais, com as que decorram «da violação da vida privada e dos direitos de personalidade, incluindo a difamação" [cfr. o artigo $1 .^{\circ}$, n. $^{\circ} 2$, alínea $g$ ) do Regulamento 864/2007, e a obra citada na nota anterior, a p. 113].

119 Por exemplo, o artigo 3. ${ }^{\circ}$ do Regulamento citado na nota anterior.

120 Tal tem sucedido após a entrada em vigor daqueles actos de direito da União Europeia, designadamente na Polónia [Lei de Direito Internacional Privado de 4 de Fevereiro de 2011, Yearbook of Private International Law, vol. 13, 2011, p. 641-656; para uma introdução à sua análise, cfr. PAJOR, T., «Introduction to the New Polish Act of Private International Law», ibid., p. 381-388, e «La nouvelle loi polonaise de droit international privé. Présentation générale», Rev. crit. de DIP, vol. 101, 2012, p. 5-13, e ERNST, U., «Das polnische IPR-Gesetz von 2011 - Mitgliedstaatliche Rekodification in Zeiten supranationaler Kompetenzwahrnehmung», RabelsZ, vol. 76, 2012, p. 597-638 e na Holanda [Lei de 19 de Maio de 2011, relativa ao Livro 10 (Direito Internacional Privado) do Código Civil Holandês, Yearbook of Private International Law, vol. 13, 2011, p. 656-694; TEN WoldE, M. H., "Codification and consolidation of Dutch Private International Law: The Book 10 Civil Code of the Netherlands», ibid., p. 389-411, e STRUYKEN, V. M., "The Codification of Dutch Private International Law - A brief introduction to Book $10 \mathrm{BV}$ », RabelsZ, vol. 78, 2014, p. 592-614, países onde os trabalhos de codificação se limitaram à matéria dos conflitos de leis, e na República Checa [Lei de direito internacional privado de 25 de Janeiro de 2012, e a análise de PAuknerovna, M. e PfeIfFER, M., «The new act on private international law in the Czech Republic: Starting points and perspectives within the European Union», Journal of Private International Law, vol. 10, núm. 2, 2014, p. 205-226, onde, diferentemente, eles incluíram as questões de competência internacional e de reconhecimento de decisões estrangeiras.

121 Apesar de existirem propostas nesse sentido. Cfr. as diversas comunicações recolhidas em op. cit., nota 86), e os trabalhos de Stefan Leible, S. e Muller, M., "The Idea of a "Rome 0" Regulation", Yearbook of Private International Law, vol. 14, 2012/2013, p. 137-152, e, mais recentemente, Hausmann, R., «Le questioni generali nel diritto internazionale privato europeo», Rivista di Diritto Internazionale Privato e Processuale, vol. 15, 2015, p. 499-522, e Von HeIN, J. e RuHL, G., «Towards a European Code on Private International Law», RabelsZ, vol. 79, 2015, p. 701-751.

${ }^{122}$ Vejam-se os artigos $16 .^{\circ}$ e $17 .^{\circ}$, e $24 .^{\circ}$ a $26 .^{\circ}$, do Regulamento $864 / 2007,9 .^{\circ}$, e $20 .^{\circ}$ a $22 .^{\circ}$, do Regulamento $593 / 2008,10 .^{\circ}$ a $15 .^{\circ}$ do Regulamento $1259 / 2010$, e $31 .^{\circ}, 33 .^{\circ}$, e $34 .^{\circ}$ a $37 .^{\circ}$, do Regulamento 650/2012, e 30. ${ }^{\circ}$ a 35..$^{\circ}$, tanto do Regulamento 2016/1103 como do Regulamento 2016/1104. Não nos referimos ao Regulamento 4/2009 na medida em que este texto se limita a remeter para o Protocolo da 
31. Pensamos assim que, no actual contexto, em que a competência normativa nacional carece de ser vista tendo em conta os desenvolvimentos do direito da União, são as questões do casamento (constituição e efeitos pessoais) e da filiação (biológica, adoptiva, incluindo as novas formas de maternidade de substituição) que poderão justificar sobretudo a atenção por parte do nosso legislador. Matérias em que, em relação ao regime actualmente em vigor, será possivelmente de esperar um reforço quer do papel reconhecido à autonomia das partes, quer das normas de conflitos inspiradas por considerações de justiça material.

\section{RESUMO}

\section{A CODIFICAÇÃO DO DIREITO INTERNACIONAL PRIVADO PORTUGUÊS EM PERSPECTIVA, MEIO SÉCULO MAIS TARDE}

O presente estudo analisa os traços fundamentais da codificação do direito internacional privado português, constante do Código Civil de 1966. Começando por situá-la na evolução desta disciplina em Portugal e na situação na altura vivida nos demais Estados europeus, o Autor refere as principais características do sistema então adoptado, assim como as opções essenciais que lhe subjazem, tanto na parte geral com na parte especial. Num segundo momento, refere-se a evolução verificada nas cinco décadas de vigência deste sistema, caracterizada pela multiplicação de soluções contidas em leis especiais, pela recepção de múltiplas regras constantes de convenções internacionais, e, posteriormente, pelo surgimento das regras de direito internacional privado da União Europeia. Desenvolvimentos que vieram reduzir drasticamente o campo de aplicação da codificação de 1966, realçando as notas de materialização, flexibilização e especialização já presentes no direito internacional privado português. Finalmente, vinca-se a continuidade de alguns paradigmas e o aparecimento ou reforço de novas ideias-força (como a constitucionalização do sistema e a acentuação da autonomia das partes) e indicam-se os reduzidos domínios em que, no futuro, poderão ter lugar novas iniciativas por parte do legislador português no domínio do direito internacional privado.

Palavras chave: codificação do Direito internacional privado, Direito internacional privado português, Código Civil português de 1966, evolução do sistema português de Direito internacional privado.

\section{ABSTRACT \\ THE CODIFICATION OF PORTUGUESE PRIVATE INTERNATIONAL LAW IN PERSPECTIVE, HALF A CENTURY LATER}

The present study deals with fundamental issues of Portuguese private international law codification, embodied in 1966 Civil Code. Placing this codification in the evolution of this matter in Portugal and in the situation existing at the time in the different european states, the Author refers the main characteristics of the system then adopted and the essential options that have been taken, either in the general or in the special part. In a second moment, the evolution that took place during the time the system has been in force is mentioned, characterized by the large number of rules contained in special laws, the recep-

Haia, de 23 de Novembro de 2007, sobre a lei aplicável às obrigações de alimentos; mas neste último texto tais regras constam dos artigos $12 .^{\circ}, 13 .^{\circ}, 16 .^{\circ}$ e $17 .^{\circ}$ 
tion of international conventions and, after, by the emergence of european union private international law. It is also stressed how these developments have stronly reduced scope of application of 1966 codification, also highligting the elements of materialisation, flexibility and specialisation already presents in portuguese private international law. Finally, permanence of some paradigms and emergence or renforcement of some leading concepts (as the constitutionalisation of the system and the deepening of parties autonomy) are stressed, and reference is made to the fields where new initiatives may be expected from Portuguese private international law legislator.

Keywords: codification of private international law, Portuguese private international law, 1966 Portuguese Civil Code, evolution of Portuguese system of private international law. 